\title{
Critical media literacy is not an option
}

\author{
Douglas Kellner · Jeff Share
}

Received: 29 December 2006/ Accepted: 10 January 2007/Published online: 7 April 2007

(C) Springer Science+Business Media, LLC 2007

\begin{abstract}
This article explores the theoretical underpinnings of critical media literacy and analyzes four different approaches to teaching it. Combining cultural studies with critical pedagogy, we argue that critical media literacy aims to expand the notion of literacy to include different forms of media culture, information and communication technologies and new media, as well as deepen the potential of literacy education to critically analyze relationships between media and audiences, information and power. A multiperspectival approach addressing issues of gender, race, class and power is used to explore the interconnections of media literacy, cultural studies and critical pedagogy. In the interest of a vibrant participatory democracy, educators need to move the discourse beyond the stage of debating whether or not critical media literacy should be taught, and instead focus energy and resources on exploring the best ways for implementing it.
\end{abstract}

Keywords Media literacy · Critical media literacy · Media education · Critical pedagogy $\cdot$ Cultural studies $\cdot$ Radical democracy

For most students in the United States, critical media literacy is not an option because it is not available; it is not even on the radar. Unlike educators in Canada, Great Britain, and Australia, many in the US are not informed enough about media literacy to even consider it. And yet, in today's multimedia world, it is insufficient to teach literacy that only addresses traditional concepts of print while ignoring the other major ways we receive, process, and create images and information. In the 21 st century, critical media literacy is an imperative for participatory democracy because new information communication technologies and a market-based media culture have fragmented, connected, converged, diversified, homogenized, flattened, broadened, and reshaped the world. These changes

D. Kellner $(\bowtie) \cdot$ J. Share

Social Sciences and Comparative Education, University of California, Los Angeles, Box 951521, 3022B Moore Hall, Los Angeles, CA 90095-1521, USA

e-mail: kellner@ucla.edu

URL: http://www.gseis.ucla.edu/faculty/kellner/kellner.html 
have been reframing the way people think and restructuring societies at local and global levels.

Critical media literacy is an educational response that expands the notion of literacy to include different forms of mass communication, popular culture, and new technologies. It deepens the potential of literacy education to critically analyze relationships between media and audiences, information, and power. Along with this mainstream analysis, alternative media production empowers students to create their own messages that can challenge media texts and narratives.

This paper explores the theoretical underpinnings of critical media literacy, examines some of the obstacles for implementing progressive pedagogical changes, and provides examples of practical applications. A multiperspectival approach addressing issues of gender, race, class, and power is used to explore the interconnections of media literacy, cultural studies, and critical pedagogy. In the contemporary era of standardized high stakes testing and corporate solicitations in public education, for the sake of radical democracy, the question we must ask is not if critical media literacy should be taught, but instead, how should we be teaching it.

\section{Approaches to media education}

In spite of the fact that media education in the US is in its infancy there is already debate about why and how to teach it (Hobbs, 1998). We have divided the field of media pedagogy into four general approaches in order to better explain the necessary elements of critical media literacy (Kellner, 1998; Kellner \& Share, 2005).

One approach to media education comes out of a fear of media and aims to protect or inoculate people against the dangers of media manipulation and addiction. This protectionist approach posits media audiences as passive victims and values traditional print culture over media culture as exemplified by Neil Postman (1985) in Amusing Ourselves to Death. Postman warns that TV has attained the power to control education because it dominates the attention, time, and cognitive habits of the youth. Many activists on both sides of the political spectrum come to media education as a way to push their agenda through blaming the media. Some conservatives blame the media for causing teen pregnancies and the destruction of family values while some on the left criticize the media for rampant consumerism and making children materialistic. From her research with preschool teachers/childcare providers, Ellen Seiter (2002) found this fear of media and popular culture greatest at middle and upper socio-economic levels. She writes, "the media are deemed most powerful by those working and living in situations of relative privilege; in the poorest center the media are seen as only one factor-less significant than the part played by poverty, by parental absence, and by violence', (pp. 59-60).

While we recognize that media contribute to and at times cause many social problems, we take issue with this approach because of its anti-media bias which over-simplifies the complexity of our relationship with media and takes away the potential for empowerment that critical pedagogy and alternative media production offer. When the understanding of media effects is contextualized within its social and historical dynamics then issues of power and ideology are extremely useful to media education to explore the interconnections between information and power (Ferguson, 2004). Critics of this anti-media approach suggest that it will cause students to either regurgitate "politically correct" responses to 
media critique or reject the ideas of media literacy altogether (Buckingham, 1994). Aspects of a protectionist approach can be useful when they address the naturalizing processes of ideology and the interrelationships with social injustice, but it is deeply flawed when it does so through dogmatic orthodoxy and undemocratic pedagogy.

A second approach to teaching about media can be seen in media arts education, where students are taught to value the aesthetic qualities of media and the arts while using their creativity for self-expression through creating art and media. These programs can be found most often inside schools as stand-alone classes or outside of the classroom in communitybased or after-school programs. While many of these programs are excellent examples of critical media literacy as we describe later in this paper, we have concerns with the media arts approach that favors individualistic self-expression over socially conscious analysis and alternative media production. Many of these programs tend to unproblematically teach students the technical skills to merely reproduce hegemonic representations with little awareness of ideological implications or any type of social critique. Feminist standpoint theorists explain that coming to voice is important for people who have seldom been allowed to speak for themselves, but without critical analysis it is not enough (Collins, 2004; Harding, 2004; Hartsock, 1997). Critical analysis that explores and exposes the structures of oppression is essential because merely coming to voice is something any racist or sexist group of people can also claim. Spaces must be opened up and opportunities created so that people in marginalized positions have the opportunity to collectively struggle against oppression, to voice their concerns, and create their own representations.

Incorporating the arts and media production into education offers the potential for making learning more experiential, hands-on, creative, expressive, and fun. Media arts education can bring pleasure and popular culture into mainstream education thereby making school more motivating and relevant to students. When this approach moves beyond technical production skills or relativist art appreciation and is steeped in cultural studies and critical pedagogy that address issues of gender, race, class, sexuality, and power, it holds dramatic potential for transformative critical media literacy.

A third approach to media education can be found in the media literacy movement in the US. While the movement is relatively small, ${ }^{1}$ it has made some inroads into mainstream educational institutions and established two national membership organizations in the US. According to the definition of media literacy provided by one of the two national media literacy organizations, The Alliance for a Media Literate America, "media literacy is seen to consist of a series of communication competencies, including the ability to ACCESS, ANALYZE, EVALUATE, and COMMUNICATE.",2 This approach attempts to expand the notion of literacy to include popular culture and multiple forms of media (music, video, Internet, advertising, etc.) while still working within a print literacy tradition.

While we agree with the need to begin with these ideas of expanding our understanding of how we communicate with more than just printed words, this is not enough to bring about a democratic reconstruction of education and society. Robert Ferguson (1998) uses the metaphor of an iceberg to explain the need for critical media analysis. Many educators working under an apolitical media literacy framework guide their students to only analyze the obvious and overt tip of the iceberg they see sticking out of the water. Ferguson asserts that this is a problem because "The vast bulk which is not immediately visible is the intellectual, historical and analytical base without which media analysis runs the risk of

\footnotetext{
${ }^{1}$ See Kellner \& Share, 2005.

2 This is part of The Alliance for a Media Literate America definition available online at: http:// www.amlainfo.org/medialit/index.php
} 
becoming superficial, mechanical or glib"' (p. 2). The critical component of media literacy must transform literacy education into an exploration of the role of language and communication to define relationships of power and domination because below the surface of that iceberg lies deeply embedded ideological notions of white supremacy, capitalist patriarchy, classism, homophobia, and other oppressive myths.

Many media educators working from this approach, openly express the belief that education can and should be politically neutral and that their job is to objectively expose students to media content without questioning ideology and issues of power. Giroux writes, "The notion that theory, facts, and inquiry can be objectively determined and used falls prey to a set of values that are both conservative and mystifying in their political orientation"' (1997, p. 11).

The mainstream appeal of the media literacy movement in the US, something that it is only just starting to develop, can probably be linked to its conservative base that does not engage the political dimensions of education and especially literacy. While this ambiguous non-partisan stance helps the dissemination of media education, thereby making some of the ideas available to more students, it also waters down the transformative potential for media education to become a powerful tool to challenge oppression and strengthen democracy. The media literacy movement has done excellent work in promoting important concepts of semiotics and intertextuality, as well as bringing popular culture into public education. However, without critical pedagogy and cultural studies, media literacy risks becoming another cookbook of conventional ideas that only improve the social reproductive function of education.

The type of critical media literacy that we propose includes aspects of the three previous models, but focuses on ideology critique and analyzing the politics of representation of crucial dimensions of gender, race, class, and sexuality; incorporating alternative media production; and expanding textual analysis to include issues of social context, control, resistance, and pleasure. A critical media literacy approach also expands literacy to include information literacy, technical literacy, multimodal literacy, and other attempts to broaden print literacy concepts to include different tools and modes of communicating (Kellner, 1998). In addition to these elements, critical media literacy brings an understanding of ideology, power, and domination that challenges relativist and apolitical notions of most media education in order to guide teachers and students in their explorations of how power and information are always linked. This approach embraces the notion of the audience as active in the process of making meaning, as a cultural struggle between dominant readings, oppositional readings or negotiated readings (Ang, 2002; Hall, 1980).

Critical media literacy thus constitutes a critique of mainstream approaches to literacy and a political project for democratic social change. This involves a multiperspectival critical inquiry, of popular culture and the cultural industries, that addresses issues of class, race, gender, sexuality, and power and also promotes the production of alternative counterhegemonic media. Media and information communication technology can be tools for empowerment when people who are most often marginalized or misrepresented in the mainstream media receive the opportunity to use these tools to tell their stories and express their concerns. For members of the dominant group, critical media literacy offers an opportunity to engage with the social realities that the majority of the world is experiencing. The new technologies of communication are powerful tools that can liberate or dominate, manipulate, or enlighten and it is imperative that educators teach their students how to use and critically analyze these media (Kellner, 2004).

The different approaches to media education are not rigid pedagogical models as much as they are interpretive reference points from which educators frame their concerns, goals, 
and strategies. Calling for critical media literacy is important to identify the elements and objectives necessary for good media pedagogy. Alan Luke and Peter Freebody have been developing a dynamic understanding of literacy as a social practice where critical competence is one of the necessary practices. This framing of literacy as a family of practices in which multiple practices are crucial and none alone are enough, fits well into our multiperspectival approach to critical media literacy. Luke and Freebody (1999) write that effective literacy requires four basic roles that allow learners to "break the code...participate in understanding and composing...use texts functionally...[and] critically analyze and transform texts by acting on knowledge that texts are not ideologically natural or neutral.', This normative approach offers the flexibility for literacy education to explore and critically engage students with the pedagogy that will work best for each teacher in their own unique situation with the different social and cultural needs and interests of his or her students and local community.

When educators teach students critical media literacy, they often begin with media arts activities or simple decoding of media texts in the mode of the established media literacy movement with discussion of how audiences receive media messages. But critical media literacy also engages students in exploring the depths of the iceberg with critical questions to challenge "common-sense" assumptions and redesign alternative media arts production with negotiated and oppositional interpretations. The goal should be to move toward critical media literacy with the understanding of literacy as a social process that requires breadth and depth, while planting seeds and scaffolding the steps for transformative pedagogy.

For example, in her course on critical media literacy at UCLA, Rhonda Hammer has her students work in teams to create their own counter-hegemonic movies and web sites that explore issues they feel are under-represented or misrepresented in the mainstream media (see Hammer, 2006). ${ }^{3}$ During the short ten-week quarter, her students produce movies and web sites that challenge the "common-sense" assumptions about a wide assortment of issues dealing with gender, ethnicity, sexuality, politics, power, and pleasure. Through the dialectic of theory and practice her students create critical alternative media while engaging the core concepts of critical media literacy as they apply to audience, text, and context.

\section{Radical democracy}

Critical media literacy in our conception is tied to the project of radical democracy and is concerned to develop skills that will enhance democratization and civic participation. It takes a comprehensive approach that teaches critical skills and how to use media as instruments of social communication and change. The technologies of communication are becoming more and more accessible to young people and ordinary citizens, and can be used to promote education, democratic self-expression, and social progress. Technologies that could help produce the end of participatory democracy, by transforming politics into media spectacles and the battle of images, and by turning spectators into passive consumers, could also be used to help invigorate democratic debate and participation.

Indeed, teaching critical media literacy should be a participatory, collaborative project. Watching television shows or films together could promote productive discussions between teachers and students (or parents and children), with emphasis on eliciting student views,

\footnotetext{
${ }^{3}$ Hammer's course web site can be viewed at: http://www.sscnet.ucla.edu/05F/womencm178-1/
} 
producing a variety of interpretations of media texts, and teaching basic principles of hermeneutics and criticism. Students and youth are often more media savvy, knowledgeable, and immersed in media culture than their teachers, and can contribute to the educational process through sharing their ideas, perceptions, and insights. Along with critical discussion, debate, and analysis, teachers ought to be guiding students in an inquiry process that deepens their critical exploration of issues that affect them and society. Since media culture is often part and parcel of students' identity and a most powerful cultural experience, teachers must be sensitive in criticizing artifacts and perceptions that students hold dear, yet an atmosphere of critical respect for difference and inquiry into the nature and effects of media culture should be promoted (Luke, 1997).

A major challenge in developing critical media literacy, however, results from the fact that it is not a pedagogy in the traditional sense with firmly-established principles, a canon of texts, and tried-and-true teaching procedures. It requires a democratic pedagogy, which involves teachers sharing power with students as they join together in the process of unveiling myths, challenging hegemony, and searching for methods of producing their own alternative media. Critical media pedagogy in the US is in its infancy; it is just beginning to produce results, and is more open and experimental than established print-oriented pedagogy. Moreover, the material of media culture is so polymorphous, multivalent, and polysemic, that it necessitates sensitivity to different readings, interpretations, perceptions of the complex images, scenes, narratives, meanings, and messages of media culture which in its own ways is as complex and challenging to critically decipher as book culture.

Teaching critical media literacy involves occupation of a site above the dichotomy of fandom and censor. One can teach how media culture provides significant statements or insights about the social world, empowering visions of gender, race, and class, or complex aesthetic structures and practices, thereby putting a positive spin on how it can provide significant contributions to education. Yet we ought to indicate also how media culture can advance sexism, racism, ethnocentrism, homophobia, and other forms of prejudice, as well as misinformation, problematic ideologies, and questionable values, accordingly promoting a dialectical approach to media.

\section{Cultural studies and critical pedagogy}

While media education has evolved from many disciplines, an important arena of theoretical work for critical media literacy comes from the multidisciplinary field of cultural studies. This is a field of critical inquiry that began over a century ago in Europe and continues to grow with new critiques of media and society. From the 1930s through the 1960s, researchers at the Frankfurt Institute for Social Research used critical social theory to analyze how popular culture and the new tools of communication technology induce ideology and social control. In the 1960s, researchers at the Centre for Contemporary Cultural Studies at the University of Birmingham added to the earlier concerns of ideology with a more sophisticated understanding of the audience as active makers of meaning, not simply mirrors of an external reality. Applying concepts of semiotics, feminism, multiculturalism, and postmodernism, a dialectical understanding of political economy, textual analysis, and audience theory has evolved in which media and popular culture can be analyzed as dynamic discourses that reproduce dominant ideologies as well as entertain, educate, and offer the possibilities for counter-hegemonic alternatives (see Kellner, 1995).

Media education that has evolved from cultural studies is defined less as a specific body of knowledge or set of skills, and more as a framework of conceptual understandings 
(Buckingham, 2003). Many people and organizations around the world have generated their own lists of concepts ${ }^{4}$ that vary in numbers and wording, but for the most part they all tend to coincide with at least five basic elements: 1 . recognition of the construction of media and communication as a social process as opposed to accepting texts as isolated neutral or transparent conveyors of information; 2. some type of textual analysis that explores the languages, genres, codes, and conventions of the text; 3 . an exploration of the role audiences play in negotiating meanings; 4. problematizing the process of representation to uncover and engage issues of ideology, power, and pleasure; 5. examination of the production and institutions that motivate and structure the media industries as corporate profit seeking businesses (see Kellner \& Share, 2005).

The core concepts of media literacy are most relevant to progressive and transformative education when taught through a democratic approach with critical pedagogy that follows the ideas of progressive educators like John Dewey and Paulo Freire. Over a century ago, Dewey championed education for democracy and placed emphasis on active learning, experimentation, and problem solving. Dewey's pragmatic approach connects theory with practice and requires students to similarly connect reflection with action (1916/1997). Using a problemposing pedagogy, Freire (1970) calls for critical consciousness that involves perception of concrete situations and problems, as well as action against oppression. The problem-posing alternative that Freire exercises requires dialogical communication between students and teachers where both are learning and teaching each other. This necessitates praxis, critical reflection together with action to transform society. For this reason, media education should involve both critical analysis and critical student media production.

Len Masterman (1994) declared that the goal for media education should be critical autonomy, so that students will want to critically question media when they are not with their teacher. Robert Ferguson (2001) suggested that students must also learn critical solidarity because one is never truly autonomous and information does not exist in isolation, it is always linked to hierarchical relationships of power. By combining the ideals of critical autonomy with critical solidarity we propose a model for radical democracy that promotes independence and interdependence but moves away from an uncritical dependency on media. When media is seen as merely transparent windows, the messages become naturalized, we become complacent and democracy ceases to be representative. Our dependency on media surrenders our active participation and civic duties to question, challenge, and correct social injustices. Radical democracy depends on individuals caring about each other, involved in social issues, and working together to build a more egalitarian less oppressive society.

\section{Alternative media production}

Many community-based after school programs like Educational Video Center (EVC) in New York City and REACH LA in Los Angeles offer excellent examples for how media production can be taught as an essential component of critical media literacy. Both programs involve inner-city youth in video production activities in which the students explore their concerns and create their own alternative media to challenge the dominant representations. Founder and Executive Director of EVC, Steven Goodman (2003) writes, "This approach to critical literacy links media analysis to production; learning about the world is

\footnotetext{
${ }^{4}$ Canada's Ontario Ministry of Education's Eight Key Concepts, British Film Institute's Signpost Questions, The Center for Media Literacy Five Core Concepts, Masterman (2001), etc.
} 
directly linked to the possibility of changing it. Command of literacy in this sense is not only a matter of performing well on standardized tests; it is a prerequisite for self-representation and autonomous citizenship"' (p. 3).

Media production at REACH LA is more than just teaching isolated skills, it is part of a structured program based on key pedagogical practices that personalize and politicize the youth and their messages. Combining the analytical skills to deconstruct mainstream media with the artistic and technical skills to construct alternative counter-hegemonic media becomes a natural process. In the Computer-Active and Digital Arts-Active programs, students learn video production, animation, digital arts, web site creation and maintenance, as well as the skills necessary to produce an annual teen magazine called REACH for Me. These technical skills incorporate their poetry, artwork, and short stories in public service campaigns for the larger goal of affecting change in their communities. Consistent with critical pedagogy, the students move from being objects of other people's research and media representations to becoming subjects empowered to tell their own stories and collectively challenge dominant oppressive myths. Goodman insists that "these possibilities can only be fully realized if the programs' guiding principles are based on a youth empowerment model; that is, teaching kids critical literacy requires that programs value and engage them as active participants in community problem-solving and as full partners in their own learning and growth" (p. 103).

REACH LA follows a Freireian problem-posing philosophy by helping students focus on problematic issues for them such as HIV/AIDS, homophobia, and racism. EVC has a different focus yet a similar approach as Goodman explains, "in addition to the myriad individual 'life skills' that are typically offered to at-risk kids, they need to be engaged in the study of the systemic roadblocks in their way—such as police brutality, unequal educational resources, substandard housing, and so on-and what sort of collective action they might take to move those roadblocks aside', (p. 3). It is these types of real-world connections that Dewey wrote about almost a century ago. This is the way to make education meaningful to students and empower them to become active participants necessary for radical democracy.

Public education

Sprinkled across the US are a relatively small number of educators in schools and outside, teaching critical media literacy to fortunate students from preschool to university. These educators often struggle against many obstacles, have to create their own materials and work in relative isolation. While support for media education is growing from the two national media literacy organizations ${ }^{5}$ and other teacher associations such as the National Council of Teachers of English (NCTE) and the National Council for the Social Studies (NCSS), media literacy is still on the fringe with little recognition and even less financial support. In the 1970s, the US Department of Education showed modest interest in critical viewing, but that ended abruptly in 1978 when the government received Senator William Proxmire's Golden Fleece Award for wasting taxpayer money to develop curriculum for teaching college students "how to watch television." 6 Since that embarrassment, public funding and support for media literacy in the US has been rare.

\footnotetext{
5 Alliance for a Media Literate America, AMLA (http://www.amlainfo.org/) and Action Coalition for Media Education, ACME (http://www.acmecoalition.org/).

${ }^{6}$ Information about the Golden Fleece Awards can be found at website of Taxpayers for Common Sense: http://www.taxpayer.net/awards/goldenfleece/1975-1980.htm
} 
At the beginning of the 21st century, the Federal government finally spent some money on media education and funded 17 demonstration projects across the country to integrate media literacy with the arts. Based at an elementary school in downtown Los Angeles, California, Project SMARTArt was one of the largest grant recipients. ${ }^{7}$ For three years students from kindergarten to fifth grade worked with teachers and artists to analyze media and create their own alternative representations of everything from violence, to advertising, to their community. Students produced animation, performed original plays, painted, wrote, photographed, and used numerous types of media to analyze, and communicate, read and write their world. Since the grant ended, the funding stopped, the support discontinued, and most of the teachers have diminished their media literacy teaching. This case offers a potent example of the importance for support on many levels, from professional development for teachers and administrators to a commitment to adequately fund resources and ongoing trainings.

One important area that has made steady progress is the official recognition of the value of media literacy as can be seen in its inclusion in State standards across the US. Today, most of the 50 states make some mention of media education in their educational standards (Kubey \& Baker, 1999). For example, in California, the State Department of Education lists the category "Analysis and Evaluation of Oral and Media Communications" as part of Language Arts for third through 12th grades. In Texas, media education is included in the state standards under the heading of Viewing and Representing within Language Arts Standards from fourth grade on. The closest equivalent the US has to national educational standards can be found at the Mid-continent Research for Education and Learning (McRel) organization. This private non-profit is a leader in educational standards for many state departments of education. Online they list Viewing (Uses viewing skills and strategies to understand and interpret visual media) and Media (Understands the characteristics and components of the media) as two of the five components of Language Arts. ${ }^{8}$ While media education is now expected to be taught since it is listed in almost all the state standards, unfortunately little has been done to train teachers, provide resources or create curriculum (see Kellner \& Share, 2005).

\section{Conclusion}

Literacy instruction needs to change and this movement must come from both the top down and the bottom up. Literacy must be reframed to expand the definition of a text to include new modes of communication and popular culture to enhance our critical analytical processes to explore audience reception, learn to critically read media texts, and aim at social justice, as well as grasping the political, economic, historical, and social contexts within which all messages are written and read.

Cultural studies and critical pedagogy offer the theoretical background to inform practice that can transform education and society. To move forward with critical media literacy we need to lobby for better funding for education, especially where it is needed most in the inner cities. We need to challenge the false wisdom of high stakes testing and deficit thinking, as well as to train teachers in critical pedagogy and empower them to use their creativity more than the scripted curricula. In addition, we need conferences, teacher education, and continuing professional development that teach cultural studies, critical

\footnotetext{
7 See case study online at: http://www.medialit.org/reading_room/article659.html

8 Available online at: http://www.mcrel.org/compendium/Standard.asp?SubjectID=7
} 
pedagogy, and practical applications for how to engage students in the classroom with critical media literacy concepts.

We recommend that media education programs be instituted from preschool to university and that linking media literacy with production become a regular practice. Standards for media literacy programs should include criticizing the ways that media reproduce racism, sexism, homophobia, and other prejudices and encouraging students to find their own voices in critiquing media culture and producing alternative representations. Media education should be connected with education for democracy where students are encouraged to become informed and media literate participants in their societies. Further, media literacy should be linked with information literacy, technological literacy, the arts, and the social sciences. Critical media literacy should be a common thread that runs through all curricular areas since it deals with communication and society.

Currently, media literacy policy in the US is in its formative years and has advanced little during the Bush-Cheney era. Policy challenges include overcoming the conservative and neo-liberal hegemony and coming up with democratic and progressive alternatives. Federal and state grants for experimental projects in media literacy can be extremely beneficial and should be pursued by educators. ${ }^{9}$ National and state conferences that specifically address the teaching of critical media literacy can provide excellent places for progressive educators and policy makers to unit and work together, sharing and building a movement. Parent groups should provide their members with resources and discussions to address the concerns they have about media and how they can teach critical media literacy in the home. Parent organizations should also use their collective power to influence school curriculum and lobby congress in support of progressive education.

The task for educators and researchers is to engage in a new type of literacy education, from pre-school to higher education that incorporates new information communication technologies, media, and popular culture with critical pedagogy. This work must challenge dominant ideologies and empower youth to unveil the myths through creating their own alternative representations that empower their own voices and struggles for social justice. The goal of this project is to help students transform themselves into socially active citizens and at the same time transform society into a less oppressive and more egalitarian democracy. Therefore, from this perspective, critical media literacy is not an option, it is an imperative.

\section{References}

Ang, I. (2002). On the politics of empirical audience research. In M. G. Durham \& D. M. Kellner (Eds.), Media and cultural studies key works (pp. 177-197). Malden: Blackwell Publishers.

Buckingham, D. (1994). Children talking television: The making of television literacy. London: The Flamer Press.

Buckingham, D. (2003). Media education: Literacy, learning and contemporary culture. Cambridge: Polity Press.

Collins, P. H. (2004). Learning from the outsider with: The sociological significance of black feminist thought. In S. Harding (Ed.), Feminist standpoint theory reader: Intellectual and political controversies (pp. 103-126). New York: Routledge.

Dewey, J. (1916/1997). Democracy and education. New York: The Free Press.

Ferguson, R. (1998). Representing 'Race': Ideology, identity and the media. New York: Oxford University Press.

Ferguson, R. (2001). Media education and the development of critical solidarity. Media Education Journal, $30,37-43$.

$\overline{9}$ See the doctoral dissertation by Jeff Share (2006). 
Ferguson, R. (2004). The media in question. London: Arnold.

Freire, P. (1970). Pedagogy of the oppressed. New York: Seabury Press.

Giroux, H. (1997). Pedagogy of the politics of hope: Theory, culture, and schooling. Boulder, CO:Westview Press.

Goodman, S. (2003). Teaching youth media: A critical guide to literacy, video production, and social change. New York. Teachers College Press.

Hall, S. (1980). Encoding/Decoding. In S. Hall, D. Hobson, A. Lowe, \& P. Willis (Eds.), Culture, media, language (pp. 128-138). London: Hutchinson.

Hammer, R. (2006). Teaching Critical Media Literacies: Theory, Praxis and Empowerment. In InterActions: UCLA Journal of Education and Information Studies, Vol. 2, Issue 1. Retrieved February 17, 2006 from, http://repositories.cdlib.org/gseis/interactions/vol2/iss1/art7/.

Harding, S. (2004). Rethinking standpoint epistemology: What is "Strong Objectivity"? In S. Harding (Ed.), Feminist standpoint theory reader: Intellectual and political controversies (pp. 127-140). New York: Routledge.

Hartsock, N. (1997). The Feminist standpoint: Developing the ground for a specifically feminist hisotrical materialism. In S. Kemp \& J. Squires (Eds.), Feminisms (pp. 152-160). New York: Oxford University Press.

Hobbs, R. (1998). The seven great debates in the media literacy movement. Journal of Communication, 48(1), 16-32.

Kellner, D. (1995). Media culture: Cultural studies, identity and politics between the modern and the postmodern. London and New York: Routledge.

Kellner, D. (1998). Multiple literacies and critical pedagogy in a multicultural society. Educational Theory, 48(1), 103-122.

Kellner, D. (2004). Technological transformation, multiple literacies, and the re-visioning of education. $E$ Learning, 1(1), 9-37.

Kellner, D., \& Share, J. (2005). Toward critical media literacy: Core concepts, debates, organizations and policy. In Discourse: Studies in the cultural politics of education Vol. 26, No. 3 (pp. 369-386). The University of Queensland, Australia: Routledge.

Kubey, R., \& Baker, F. (1999). Has media literacy found a curricular foothold? Education Week, 19(9), 3856.

Luke, C. (1997). Media literacy and cultural studies. In S. Muspratt, A. Luke, \& P. Freebody (Eds.), Constructing critical literacies: Teaching \& learning textual practice (pp. 19-49). Cresskill, NJ: Hampton Press, Inc.

Luke, A., \& Freebody, P. (1999). Further notes on the four resources model. Reading Online. Retrieved February 12, 2006, from http://www.readingonline.org/research/lukefreebody.html.

Masterman, L. (2001). Teaching the media. New York: Routledge.

Masterman, L. (1994). A rationale for media education (First Part). In L. Masterman \& F. Mariet (Eds.), Media education in 1990s' Europe (pp. 5-87). Strasbourg: Council of Europe.

Postman, N. (1985). Amusing ourselves to death: Public discourse in the age of show business. New York: Penguin Books.

Seiter, E. (2002). Television and new media audiences. New York: Oxford University Press.

Share, J. (2006). Critical media literacy is elementary: A case study of teachers' ideas and experiences with media education and young children. Unpublished doctoral dissertation, University of California, Los Angeles. 